\title{
The Contrastive Study and Translation Strategies on Conceptual Metaphor in Chinese and English Political Discourses
}

\author{
Lin Zu, Xiaokun Zhai \\ English Department, North China Electric Power University (BaoDing), China \\ zulin3188@163.com, carakun@163.com
}

\begin{abstract}
This thesis is intended to make a contrastive analysis with regard to the use of metaphors the public speeches at foreign university made by the American politicians and by the Chinese politicians with the guidance of Layoff's conceptual metaphor theory so as to find out the similarities and differences in metaphors in Chinese and English political discourses. The ultimate purpose of this thesis is to put forward some strategies, which will benefit future metaphor translation.

Index Terms - contrastive analysis, translation strategies, conceptual metaphor theory, political discourses

\section{Introduction}

Since Aristotle, metaphor has already become one of hot topics in the study of linguists [1]. The western traditional views claim metaphor as a rhetorical device. The conceptual metaphor theory is well known for the research carried out by Lakoff \& Johnson, whose book, Metaphors We Live By in 1980 shapes the basic framework for modern metaphor cognitive theory. Majorities of the research on political language are done from the aspect of rhetoric and pragmatics. The current study targets to deal with political discourse by the guidance of metaphor, and focuses mainly on politicians' speech at foreign university, which is few involved in previous research.
\end{abstract}

\section{Theoretical Framework}

It is a great breakthrough that Lakoff and Johnson bring about the idea that "metaphor is pervasive in everyday life, not just in language but in thought and action. Our ordinary conceptual system, in terms of which we both think and act, is fundamentally metaphorically in nature" [2]. That is to say, we cannot get along well without metaphor. And they also explain that the essence of metaphor is understanding and experiencing one kind of thing in terms of another[3].

In the book Metaphors We Live By, Lakoff and Johnson classify conceptual metaphors into three types according to their cognitive functions: structural metaphors, orientation metaphors, and ontological metaphors [4]. Put it simply, the expression of conceptual metaphor involves "a cross-domain mapping from a concrete source domain to an abstract target domain, thus, the mapping constitutes a "one-to-one" relationship between the certain words in the two domains" [5]. That is to say, conceptual metaphor is the structure mapping of the between concept domains.

\section{The Contrastive Study on Conceptual Metaphor in Chinese and English Political Discourses}

\subsection{Data Collection}

The research data of this thesis are taken from the public speeches at foreign university made by the American politicians and by the Chinese politicians, some of which have the official translation version. The data are composed of 15 American texts and the same amount of Chinese texts to ensure the accuracy and reliability of the research finding. These data are selected from the newspaper and internet from 2003 to 2014.

\subsection{Contrastive Analysis and Discussion}

Political discourses aim to persuade the listeners to believe what the speaker delivers and thus follow him. Metaphor, which is closely related to human experience, can make abstract and implicated issues easy to understand [6]. In this way, metaphor must be frequently applied by politicians. After careful analysis of the data, the author finds that the main conceptual metaphors identified in American and Chinese corpora including journey metaphor, organism metaphor, war metaphor, religion metaphor, circle metaphor. Among them, journey metaphor, organism metaphor and war metaphor and family metaphor are used both by American and Chinese politicians while religion metaphor is unique to American data and circle metaphor is unique to Chinese data.

\subsubsection{Same Conceptual Metaphors in both Corpora}

\subsubsection{Journey Metaphor}

The experience of journey is familiar to all of us. When a predetermined destination is set, and the planned route is chosen, we are beginning a journey. Similarly, when a country or party has its settled political goal and policies, we can say it is on its journey. The journey metaphor is widely employed in both data, for example:

(1) 中国人民经过长期不解的斗争建立了新中国, 又 经过艰苦的探索, 终于找到了适合国情的发展道路一中 国特色社会主义道路, 文明古国焕发了青春活力。(温家 宝，2009)

The conceptual metaphor uses by Premier Wen Jia Bao in the speech at the University of Cambridge on 2nd February 2009 is "THE EXPLORATION IS A JOUTNEY". As we all 
know, the image of "journey"implies a starting point where a traveler is determined to take his rout, an arranged path along which one can be led to the destination, some difficulties and hardships one is supposed to overcome by unremitting efforts, as well as a goal which is where the objective of the journey lies. In the above instance, “中国人民” are the travelers who is granted the right to choose the journey path all by themselves; “新中国”is the goal which every Chinese people has tries his best to achieve; and “中国特色社会主义道路”is the planned path and it is the unswerving belief that the path will lead China to a brighter and more prosperous future.

(2) As long as we are joined in common purpose, as long as we maintain our common resolve, our journey moves forward, and our future is hopeful, and the state of our Union will always be strong. (Obama, 2009)

\subsubsection{Organism Metaphor}

Organism refers to a class of living things including plants and animals, among which human beings are a special and complicated kind. Living creatures are common experience shared by all cultures. A nation can be endowed with life, in this way, the conceptual metaphor "A NATION IS A PERSON" is formed in which a nation is considered as a person, whose body needs to be nurtured, mind needs to be civilized and career needs to be projected. So organism metaphor occurs in both American and Chinese political discourses. Let us take a look at examples:

(3) 新中国的廹生改变了世界力量对比和国际战略格 局, 是对帝国主义体系的沉重打击, 被帝国主义列强视为 眼中钉, 必欲扼杀于摇篮而后快。(傅莹, 2011)

“新中国” is a an infant in the cradle, and he will go through the process of being born, grow stronger and establish himself, during which he will certainly overcome some setbacks.

(4) All of these changes will lead to a stronger, more confident China, a China that can astonish and enrich the world, a China that your generation will help create.( Bush, 2002)

Difficulties will give country wisdom; chances will bring changes and progress, making it stronger and more prosperous.

\subsubsection{Building Metaphor}

A building is completed brick by brick; a society is founded step by step. In both American and Chinese cultures, the development of the nation or society all can be seen as a building, So the conceptual metaphor "A SOCIETY IS A BUILDIGN" is easy to derived. Here are two instances: 2009)

（5）中欧合作基础坚实, 前景光明。（温家宝,

The cooperation is here regarded as a building which can maintain for a long time under the condition that the basis is firmly founded.

(6) I come here today to talk to you, the next generation of China's leaders, about the critical importance to your future of building a strong partnership between China and the United States. (Clinton, 1998)

\subsubsection{Conceptual Metaphors Unique to Each Corpus}

\subsubsection{Circle Metaphor Unique to Chinese Corpus}

In Chinese, the commander of the nation is the Communist Party, who is the heart in the political life. In Chinese ideology, the leader should be located in the center, the very part of the greatest importance. So the metaphor "A PARTY IS THE CENTER" comes into being.

(7) 更加紧密团结在以胡锦涛同志为总书记的党中央 周围, 高举邓小平理论和“三个代表”重要思想伟大旗帜。 (温家宝，2010)

This is a typical circle metaphor, the Communist Party of Chinese stands in the center with people and other parties surrounding it. This phenomenon is unique to Chinese, because America applies a different political system; two parties are in power alternatively, therefore, there is no center.

\subsubsection{Religion Metaphor Unique to American Corpus}

In America, religion occupies an important part in history and culture. Most American are Christians, so American politicians involve religion metaphor a lot to make religion a spiritual power. Here is an example:

(8) We must show courage in a time of blessing by confronting problems instead of passing them on to future generations. (Biden, 2010)

In USA, religion, especially Christianity, permeates nearly every aspect of physical and mental world, having a profound influence on language. On the contrary, in China, most of the people do not have religious belief. Thus, there is nearly no Religion Metaphor in Chinese speeches.

\section{Strategies for Conceptual Metaphor Translation}

\subsection{Same Metaphors: Source-oriented Translation (Literal Translation)}

Source-oriented translation refers to the approaches to translation in which the translator retains the original cultural characteristics and style as much as possible, focusing mainly on the source language [7]. The generation of metaphors is closely related to and human practice experience in the natural and social environment. Although English and Chinese are two different language systems attached to various cultural backgrounds, they have similar or same conceptual metaphor mapping because of the same physical structure, cognitive ability, and similar practice experience. So, when translating the same conceptual metaphors in both corpora, we can use source-oriented translation or literal translation. For example:

（9）香港问题的圆满解决，经贸、文教、科技等领域 的有效合作, 为发展中英全面战略伙伴矢系奠定了坚实基 础。(温家宝，2009)

The successful resolution of the question of Hong Kong and fruitful cooperation between our two countries in areas such as economy, trade, culture, education, science and technology have cemented the foundation of our comprehensive strategic partnership.

In the Chinese speech, a building metaphor "PARTNERSHIP IS A BUILDING" can be derived. Many 
conditions in terms of economy, trade, culture, education and so on contribute a lot to the successful establishment of partnership, so conditions are "bricks" to the "partnership building". This shift of image is comprehensible to both source and target languages, thus a word-to-word translation is employed. 2009)

(10) 我深深爱着的祖国一古老而又年轻。(温家宝,

My beloved motherland is a country both old and young.

"A NATION IS A PERSON" is used in Wen Jiabao's speech, which is delivered at the University of Cambridge. A nation and a person share the same process of growing older, from being green-handed to being seasoned. The experience of growing from young to old is a common sense to both cultures, and a literal translation can work well.

(11) I think that our two countries each country should outline their own way to go. (Obama, 2010) 路。

我认为我们两国每个国家都应该公画出自己要走的

This journey metaphor is chosen from Obama's speech at Fudan University. "THE DEVELPOMENT IS A JOURNEY" also makes sense to Chinese - every independent country is on its own journey and it has the right to choose and design the path of its own.

\subsection{Different Metaphor: Target- oriented Translation}

Nida is the representative figure who proposes targetoriented translation. He claims that "target-oriented translation can eliminate cultural barriers between the source language and target language" [8]; translation should mainly take the readers' language and cultural convention into consideration. The identical image in both American and Chinese culture are limited, which makes it impossible to translate all the conceptual metaphor literally, when it comes to different metaphors, the translator may adapt the metaphor or translate it liberally. In the cases when adaptation strategy is employed, metaphor, as an expression method is maintained, but the kind of the metaphor in the original text has to be shifted to another kind. While liberal translation means an complete abolishment of the original metaphor, which is turned into meaningrelevant words or expressions.

\subsubsection{Adaptation}

As a result of the various history and social background, some images cannot be projected to a different culture, which requires the translator to adapt the original metaphor to another kind of metaphor. Take a religion metaphor in American speech as an example:

(12) Guided by the ancient vision of a promised land, let us set our sights upon a land of new promise. (Clinton, 1997)

在“希望之乡”这一古老憧憬的指引下, 让我们着眼于 新的“希望之乡”。
The above research shows that the religion metaphor occurs only in American corpus, because Christianity bears no popularity in China. If "a promised land" ,"a land of new promise" are translated as “应许之地”, the original meaning cannot be conveyed perfectly. A proper approach is to adapt the metaphor, and in this way, “希望之乡” ("the dream land") which shares the similar image with "a promised land" is considered an acceptable translation.

\subsubsection{Liberal Translation}

The translation of metaphor should reach a meaning equivalence rather than a vocabulary one [9]. So the aim of metaphor translation is to get the unfamiliar target culture well expressed to the readers. For example:

(13) 其核心目的就是通过集体合作共同维护安全，促 进发展。(王亚光, 2004)

Its major objective was to jointly safeguard security and promote development through collective action.

“核心” means the most important part in the center of a circle. The circle metaphor is unique to Chinese culture. Because of history and social basis, if the circle metaphor is translated word by word, Americans cannot get it across. Thus, in the official version, “核心目的” is liberally translated by "major objective", which gives an appropriate expression of the target domain.

\section{Conclusion}

By analyzing the conceptual metaphor in university speech by American and Chinese politicians from 2003 to 2014, the author finds that conceptual metaphors permeate in both data, and lists the similarities and differences, and in the part four discusses such translation tragedies as literal translation, adaptation and liberal translation, which will benefit conceptual metaphor translation in political discourses.

\section{References}

[1] Aristotle. Rhetoric and Poetics, New York: the modern library, pp. 13$15,1954$.

[2] Lakoff, G. \& Johnson, M. Metaphors We Live By, Chicago: University of Chicago Press, pp. 3-4, 1980.

[3] Y. Wang, Cognitive linguistics, Shanghai: Shanghai foreign language education press, pp. 36-40, 2007.

[4] Fauconnier, G. Mappings in Thought and Language, Cambridge, U. K.: Cambridge University Press, pp. 17-19, 1997.

[5] Ungerer, F. An introduction to cognitive linguistics, Beijing: foreign language teaching and research press, pp. 90-108, 2001.

[6] Jeffery, M. \& Albert, N. K. Metaphor: Implications and Applications, New Jersey: Lawrence Erlbaum Associations Publishers, pp. 219-223, 1996.

[7] P. J. Zhang, English-Chinese translation tutorial, Beijing: national defence industry press, pp. 33-35, 2008.

[8] Nida, E. A. Language, Culture, and Translating, Shanghai: Shanghai Foreign Language Edueation Press, pp. 77-85, 1993.

[9] Newmark, P. Approaches to Translation, Shanghai: Shanghai Foreign Language Education Press, pp.156-160, 2001. 